\title{
AFFIRMATION AND RETRACTION IN GOLDEN AGE DRAMA
}

In 1609, Lope de Vega wrote a treatise on dramatic art which he called Arte nuevo de hacer comedias en este tiempo. ${ }^{1}$ This short, rhymed ars poetica has been for years a controversial piece. Not because, as one might suspect at first, of discrepancies between it and what Lope practiced as a dramatist, but because Lope's position with respect to the matter he deals with is curiously ambiguous.

As the title indicates, he wishes to show how plays in his time should be written. The allusion to chronology, with its implication of contrast to another time, recalls at once the problem of the unities. This perennial problem of the theater of the 16th and 17th centuries has but scant relevance for the theater of the Spanish Golden Age. ${ }^{2}$ The Comedia cannot be accused of trying to follow the unities and failing or even of wanting to follow them. Although Lope claims, in this treatise, to have written six of his dramas according to the Aristotelian precepts, no one has ever found them. The work is interesting because Lope variously insists that he ignores the unities in the writing of his dramas, berates the ignorant public for forcing him to write this kind of play, and excuses himself for his seeming lack of artistic integrity. ${ }^{3}$

Although Lope was immensely popular, this formal stock-taking might have suggested to the playwright that his fame rested on fragile artistic grounds. ${ }^{4}$ After all, popular theater was not quite a respectable literary activity. The immense quantity of material attacking it, ${ }^{5}$ the bad reputation of the actors might have contributed to a feeling of uncertainty on the part of Lope. It is not unreasonable to suggest that Lope wished to solidify his reputation by a show of erudition and by presenting himself as superior to the public for which he was writing.

The first important reaction to Lope's treatise is, as it is for many other aspects of Spanish literary history, that of Marcelino Menéndez Pelayo. ${ }^{6}$ Don Marcelino, whose tastes were influenced both by his religious orthodoxy and his early study of Horace, could interpret Lope's contradictions only in terms of a palinode or abandonment of his position. For him, the Arte nuevo is an artistic mea culpa on the part of a writer who should have known better.

A totally different approach is taken by Ramón Menéndez Pidal. ${ }^{7}$ The great critic, with the energy that characterizes his work, wants to view Lope's utterances as an affirmation of artistic independence. For him, Lope is a man who strikes against the conventions of his time and boldly presses for his own vision of dramatic expression. The two positions are evidently antagonistic: on one side we have Menéndez Pelayo insisting that Lope flirts with a new attitude toward art but eventually recants; on the other, Menéndez Pidal affirming that Lope does not hesitate to treat unities with 
irony and then move on to an assertion of the rights of the artist. I have always been uneasy about Menéndez Pidal's anachronistic view of the self-aware artist. The period in which Lope lived with its myriad rules and compilations, guides and compendia, works toward a restriction of an individualistic conception of the world and toward an acceptance of a general view. It is not my purpose to trace the modification of these two positions by later critics. ${ }^{8}$ I have chosen the two examples to show the polarity of views that reflects more the bias of their exponents than the reality of the situation. I should like to deny Menéndez Pelayo's contention that Lope never doubted the validity of the rules and that, therefore, the Arte nuevo is a formal recantation of what he did in his plays and reject, at the same time, Menéndez Pidal's suggestion of the affirmation of artistic individuality. Menéndez Pelayo's view is unconvincing because it is not psychologically possible for a man to write hundreds of plays in one mode while believing that the dramatic structure dictated by the unities was really preferable. Menéndez Pidal's position is unacceptable because it goes contrary to the concept of artistic integrity then prevalent.

It is possible to avoid such pitfalls by proposing that Lope rejected the artistic necessity to follow the Aristotelian precepts, but that because of affinity or artistic tradition, he did not have the courage or the willingness to ignore the demands of literary authority. He was moving toward a greater consciousness of what we now accept as the innate independence of the artist, but was not capable of affirming this independence. It is the ambiguity with respect to tradition that interests me, and it is my purpose to show that, like in the Arte nuevo, the playwrights advance a position which, once they become aware of its implications, they are unable to sustain.

In an early article on the ideology of the Baroque period, Stephen Gilman remarked that the attention of that society was never focused on individual problems which could be solved, but on an over-all vision of a world irremediably immersed in chaos. ${ }^{9}$ This denial of the importance of the immediate reality corresponded to a well-delineated program of systematic undermining of the senses to affirm the greater value of the after-life. While not all of the Comedia partakes of this pessimism and subsequent yearning for disabusement, there is enough rigidity, enough reliance on set values, enough insistence on the absolute and given nature of things, to make the Golden Age theater fairly representative of a view of life best exemplified by ascetic literature.

For this reason, we have come to accept the idea that the Comedia is a conceptionally static art whose reluctance to come to grips with the every day reality of man is its most noted characteristic. The Comedia refuses to particularize: it lumps one man together with another, refusing to give him individuality, unwilling to see one man's problems as a consequence of a particular personality acting within a specific context, and maintaining the vision of an abstract man whose only important sentiments are those that 
he shares with other men. Dramatists, significantly, seldom try to find for their personages names that reflect individuality. Instead, this theater is peopled with countless Ineses, Leonores, Anas to such a degree that these few names become almost generic labels.

This static, unbelievably hierarchical world, where social ambition or peculiarities can be equated to either sin or a disruption of the great chain of being, could not maintain forever its compactness. Sooner or later, however limited they were by their conception of society, the dramatists had to approach the creative process without dragging the burden of their ideology into every scene. When this happened, they were forced to consider the particular nature of their creations and only the most willful effort could bring them back on the absolutist path of their principles. Nevertheless, this deviation from a cultural pattern did not occur consciously, rather it materialized under the influence of the events they were narrating.

The idea that human actions and emotions should be judged according to principles is normally strong enough to prevent any protracted consideration of the context of the events. But some lapses do occur because, as Gilman shows, the writer is caught in a struggle between faith in the religious-political structure of his society and his desire to express his vision. While the Comedia, on the whole, reflects the common man's strong faith in the cultural values of his society, the dramatists, because of their intellectual background, belong to a class whose task it is normally to express a particular viewpoint. Instead, officially and professionally, they helped to maintain the prevalent mores with only occasional excursions into a more personal vision of human conduct. ${ }^{10}$ The post-Romantic period, so accustomed to viewing the writer as an affirmer of the individual's rights against the demands of society, accepts with considerable difficulty a situation in which the writer argues for the rights of society against the excesses of individuals. The defense of personal rights is not a preoccupation of the Golden Age, and it does not enter literature until social conditions convince writers of the crippling consequences of authoritarian structures. ${ }^{11}$

It is to be expected, therefore, that the delving into the circumstances of events on the part of our dramatists, with its resultant ambiguity, is desultory rather than programmatic and does not allow itself to dominate the theme or the resolution of the play. It is immensely significant to me that Lope's Arte nuevo should fit so neatly with this timid approach to reality and subsequent flight into the secure arms of authority that typifies much of Golden Age theater. In order to sustain these generalizations, it will be necessary to buttress them with clear-cut examples. To this end, I have chosen to discuss plays whose social and political implications give an opportunity to explore the problem.

Lope de Vega's Fuenteovejuna, easily his most renowned play, offers such an occasion. The action is based on a historic event narrated in the 
chronicle of the orders of chivalry by Rades de Andrade. During the struggle between Isabel the Catholic and Juana la Beltraneja for the succession to the Castilian throne, the Comendador of the order of Calatrava sided with the Portuguese pretender against Isabel. He was a feudal lord whose lands included the town of Fuenteovejuna. A man of insatiable sexual appetite, he conducted a systematic campaign of seductions and violations against the women of Fuenteovejuna until the town, unable to tolerate further indignities revolted, attacked his palace, killed his servants, murdered the Comendador, and lacerated his body. The historical events are then nothing but a clear example of medieval brutality on the part of the Comendador and an equally violent popular reaction to intolerable conditions. The studies of many critics, among which are those of Leo Spitzer, William McCrary and Geoffrey Ribbans, ${ }^{12}$ have made it abundantly clear that Lope did not cast this information either in the form of a meaningless chronicle of events, or in the shape of an outright political rebellion. Lope, receptive to neo-platonic ideas, elaborated it into a theme in which an ideal society is first disrupted by barbarians and is then restored to its pristine calm. However, the recognition that the theme of Fuenteovejuna is the disruption and reestablishment of harmony in society as a reflection of universal order, does not deny the immanent import of the events. There are in the play two levels, the first, the elaboration of a neo-platonic theme; the second, the relationship between governors and governed.

The setting of the play needs to be carefully circumscribed because of its literary-cultural implications. If we accept Prof. Gilman's assertion that the intellectual response to the spiritual offensive of the CounterReformation was either escape into solitude or joining the chorus of celebrators of the national values, the return to the rural world best fits the first alternative. Marcel Bataillon, in explaining the vogue of the pastoral genre, asserts that it is due in good part to the peculiar condition of the converso and his need to find refuge in "alguna imaginación bella y melancólica." 13 The world of Fuenteovejuna is not the same as the pastoral world since it belongs to the court-country duality that was so dear to the writers of the Spanish Golden Age. ${ }^{14}$ Nevertheless, the two variants help to sustain each other, since they come from the same root. This symbiosis ensures the popularity of the two themes although the pastoral is normally interpreted as reflecting a rejection of Counter-Reformation Spain while the rural is seen as a device to sing the praises of this same society. ${ }^{15}$ There is sufficient ambiguity, then, to sustain this feeling of uncertainty of motives that we have remarked in Lope's treatise and which we shall see repeated in the plays to be discussed.

In an important essay on one of the components of the structure of Fuenteovejuna, R. F. Pring-Mill established that the tone of the play is, in his word, sententious. ${ }^{16}$ That is, the action is viewed and commented in generic terms. Pring-Mill counted nearly sixty different utterances in the 
play, that direct our attention not to the circumstances of the events but rather to abstract rules of conduct. Time after time, Lope reflects upon the action by the use of aphoristic expressions that point to the existence of explicit or implied rules of behavior. This is in perfect consonance with his theme. After all, as I have said, he is trying by means of a very complex pattern of events, to establish the inextricable unity that exists between the largest and the smallest unit. $\mathrm{He}$ is developing the topic of the microcosm-macrocosm connection. ${ }^{17} \mathrm{He}$ is talking about the relationship between men and norms. It is with a definite intention that he has one of the villagers cry in the middle of the revolt: "mueran los inormes," that is, death to those who live ex norma. Lope evidently chooses a historic event, dramatizes it along the urbs-rus duality, infuses the action with the neo-platonic sentiment of the inherent connection between all of the elements of the universe and develops it along generic lines of conduct by the repeated use of sententious remarks. One expects that having chosen this perspective, he would come to a conclusion consistent with the original intention of the play. But something very strange begins to happen. Spitzer, in his analysis of the play, underlined the ambiguity of the situation when he remarked that the villagers' cry, as they attack the palace, is "mueran los tiranos". Now, the Spanish language uses the article both to indicate the generic and the particular, and this leaves one with the problem of interpreting the battlecry either as death to all tyrants or death to these particular tyrants. Is Lope expounding a political position or uttering a cry of revenge? The question is not as idle as it seems since one of the villagers, during the discussion preceding the revolt, had rejected the alternative of an uprising because he felt that in all these affairs, it is always the poor farmers who have to shoulder most of the responsibility for the action and the subsequent reprisals (II, i).

In any event, the uprising takes place, the Comendador is killed and the populace feels free from tyranny. At this point, the general theme of order and balance is allowed to interfere with the historical circumstances. The king and queen, whose hold on the throne had been threatened by the revolt of the Comendador, his alliance with the enemy, and the subsequent seduction of the young Master of the order into joining him, instead of feeling a sense of relief that such a powerful enemy is finally out of the way, feel compelled to look into the matter because a grave breach of the feudal bond and an intolerable infraction against the concept of obedience to authority has taken place. The monarchs' apprehension regarding the rupture of this temporal and cosmic harmony is such that they dispatch an investigator to look into the matter. This psychological and dramatically invalid action on the part of the monarchs is disturbing because Lope had another and more acceptable way of solving the matter. After all, the Comendador is but a discordant element threatening the harmony of society and hence susceptible to purging. His death at the hands of the peasants fits in very well with the theme of the play. 
The investigation takes place and the dramatist, in a few short scenes, establishes the unbreakable unity of the town, thus creating for Ferdinand and Isabel an unresolvable dilemma. On the one hand, there is a feudal lord who has rebelled against his king, allied himself with the enemy, caused disorder in the kingdom, seduced countless village girls, raped and abducted others, insulted the village elders publically. On the other, there are peasants, proud of their adherence to Christianity, pure of blood, in harmony with one another, and faithful to their king. The play, as Pring-Mill proved, has been developed on the basis of universal connections and all-encompassing themes. Moreover, this total integration has been underlined by the use of aphoristic or sententious formulations whose purpose it is to generalize the action. It would seem, therefore, that the king has only two alternatives that fit the mood and the structure of the play:

1. Maintain that all rebellion is wicked and hence punishable. In this case, the killing of the traitorous Comendador could be seen as a fitting punishment that requires no further action;

2. support the right of the villagers to defend themselves against the insults and outrages of the Comendador. The King does neither. His insistence that the culprits for the death of Fernán Gómez be found and punished strikes an inconsistent chord, and the final conclusion that since the guilty persons could not be identified, the king will allow the matter to stand as is, is disappointingly anti-climactic.

This sudden plunge into relativism and circumstantiality is totally alien to the spirit of the play, to its theme and to its formulation. The playwright has prepared us for a ringing endorsement of the villagers' actions and instead ends up with a pronouncement that weakens the entire structure of the play. It is as if Lope had suddenly become aware of the implications inherent in the events and hurriedly decided that he could not make the play come to its natural conclusion. The polarity between the virtuous peasant and the immoral Comendador has been developed with an eye to the eventual expunging of the dissident element of society and the glorification of the villagers and what they represent. However, the approval of the villagers encompasses the acceptance of rebellion against sanctioned authority, and while the dramatist wishes to establish the greater moral value of the people of Fuenteovejuna, he is not ready to give them the right to affirm their rights through rebellion.

The idealization of the Spanish peasant is due both to a literary and social influence. The literary is derived from Greek and Latin bucolic poetry while the social is related, as I have indicated, to the problem of the converted Semitic element of Spain. It has to do with the identity crisis that the Spanish people underwent for some two hundred years and which coincides with their period of literary and political splendor. Both the nobility and bourgeoisie came to be suspected of having Jewish or Moorish blood and for this reason, impure blood. This impurity is connected more 
to religious orthodoxy than to racial integrity but it still implies separation and discrimination. Américo Castro has insisted that the idealization of the Spanish peasant found in the drama of the period, is nothing but a sublimation of the social conflict then raging in the peninsula, reducing thereby, the importance of the literary topos. ${ }^{18}$ An appreciation of this still controversial view of Spanish cultural history is necessary to place the discussion of the next play, Lope's Peribáñez, in a proper context.

The full title, Peribánez y el Comendador de Ocaña is important because it illustrates the theme of the play. Once again, there exists a contrastive situation, two protagonists, one representing the nobility and the other the peasantry. E. M. Wilson, in a famous article, ${ }^{19}$ analyzed this duality and found that Lope develops the images of the play in consonance with the position of the main personages. All the images that refer to Peribáñez are taken from the field and from nature in general, while those that refer to the Comendador deal with courtly subjects. Thus, both the title and the exposition of the work point toward a play of opposites with its implication of contrasts between two styles of life.

Peribáñez's life is characterized by his happy marriage with Casilda, thus joining a further blessing to his perfect state as a man at peace with himself, respected by his friends and in communion with nature. The Comendador, on the other hand, is first seen in a symbolic fall from his horse. This frequent event of the Comedia represents a person's inability to control his passions and, in neo-platonic terms, he falls below humanity into the realm of animals, thus removing himself further from those who possess intellect and are able to perceive God. ${ }^{20}$ The mishap causes the Comendador to be aided by the peasants and, when he awakens among them he sees Casilda, for whom he immediately develops an uncontrollable passion. The rest of the play deals with his attempts to seduce Casilda and final attempt at forcing his way into her bedroom during Peribáñez's absence.

The rejection of a circumstantial view of things is well illustrated by Lope's attitude toward the Comendador. He is the opposite of the other Comendador in Fuenteovejuna. The latter is a brutal animal whose enormous sexual appetite leads him to excesses; the Comendador of Ocaña is a man who truly falls in love with Casilda. However, the Comedia does not recognize any love relationship other than one between two unmarried persons or between husband and wife. Any other kind of attachment is automatically immoral. No matter how truly in love the Comendador may be, the very fact that he directs his affection toward a married woman is a sign of disruption and of misdirected sentiments. Thus no refining or defining is possible; sincerity in affection does not balance the essential transgression of the act. The Comedia often sets up irreconcilable opposites: the honorable peasant in perfect harmony with nature and participating in a divinely sanctioned union with a woman who is equally virtuous is opposed to a nobleman who is defined in courtly 
terms and associated with New Christians. ${ }^{21}$ The village girls' pun ("La compañía/de los hidalgos cansados", III, vi) was easily understood by the audience and indirectly serves to characterize the Comendador and his ilk.

Peribáñez is a complete man and he is not a peasant out of caprice but because, in this theater, the peasant incorporates within himself all those virtues that the courtly man does not and cannot possess. Peribáñez as a peasant and old Christian, symbolizes the human perfection that is inherent in his relationship between himself and his fellow-peasants, between himself and his wife, between himself and his liege lord, between himself and his God. It becomes extremely important at this time to recall that the ideal of the complete man is not a way of presenting an extraordinary personality. Golden Age drama deals often with types, and the type of the good man requires integrity, that is, wholeness of being, a personality that admits no flaw. Man, the pequeño mundo that he is, cannot allow any disturbing element within himself. This perception of man is central to the conception of the good man as it is to an understanding of the play.

Now, since this drama is based on a play of opposites, it is unavoidable that the Comendador should be presented as a reverse of Peribáñez. One can appreciate why the sincerity of the Comendador's passion cannot be recognized as a redefining agent. The conception of man as an integer cannot allow for extenuating circumstances or shades of positions. In the Comedia, one single action, one word, is sufficient to establish a character. The Comendador blinded by his passion, tries one or another way of trapping the honorable Casilda. Finally, he hits upon the idea of making Peribánez a captain of a company of peasants going to fight in the war against the Moors. ${ }^{22}$ The parallel to King David's action in sending Bathsheba's husband to his death is not to be discounted since it serves to increase the nobleman's culpability and therefore the contradistinction to Peribáñez.

The elevation of the peasant to a "caballero pardo" is the disturbing element of this play and one that creates severe ideological difficulties. The dubbing of Peribáñez (III, ii) can be seen as another measure of his worth, but since the intention of the Comendador in knighting him responds to an illicit intention, the honor is not clearly established.

When Peribáñez leaves town, the Comendador hardly waits till night falls before trying his luck. He sneaks into Casilda's bedroom while Peribáñez, who had earlier suspected the Comendador's unnatural interest in him, decides to come back into the village to see if things are all right. His return permits him to witness the virtuous protestations of his wife and the Comendador's vile attempts at forcing her. The newly-made captain draws his sword and runs the seducer through. The action is, of course, what one might expect of an individual jealous of his honor. The many plays that repeat this theme have obscured the tremendous social significance of this action. That a lowly peasant should dare to maintain 
that he possesses honor and then defend it against his liege lord is indeed extraordinary. The king's words upon hearing of the case best illustrate this point:

\author{
¡Qué un labrador tan humilde \\ estime tanto su fama! \\ ¡Vive Dios, que no es razón \\ matarle! Yo le hago gracia \\ de la vida. . . Mas iqué digo? \\ Esto justicia se llama. (III, xxvii)
}

The play ends then with Peribáñez's revenge and the king's sanction of the action.

It all seems very proper until we begin to consider the events in light of Peribáñez's position in the natural order. The peasant's revenge does not fit in at all with the prevalent ideas on the duties of a lowly personage toward his "señor natural". ${ }^{23}$ Rebellion was considered the gravest possible sin and, in the eyes of the period, akin to a rebellion against God. ${ }^{24}$ Peribáñez himself is aware of the import of his action when, upon killing the Comendador exclaims: "Perdonad, Comendador;/ que la honra es encomienda/ de mayor autoridad" (III, xvii). How, then, are we to view Peribáñez in light of this incident? What happens to the integrity of his personality if the rebellious element needs to intervene? In defending his honor, he has had to choose between two choices that must by necessity alter his being: he must choose between dishonor and rebellion. In Hamlet, the difficult alternatives are made the basis of the tragedy and Shakespeare allows the inevitable movement of the play to unfold its disastrous consequences. However, Lope's play carries none of these implications although the good man, in defending his honor, has had to give up the perfection of his being. Such an ending, with its implications of personal tragedy, could have been a satisfactory conclusion. The king's intervention, however, which establishes beyond any doubt the justice of Peribáñez's action, does not allow for such ambiguity. The reader is left with the problem of reconciling the concept of wholeness and Peribáñez's rebellious act.

This dilemma was in Roberto Sánchez's mind when he approached the play. However, his suggestion that Peribáñez's ennoblement must be considered an ironic event and that the murder is a just punishment for the Comendador's failures, begs the question. ${ }^{25}$ Peribáñez does ask to be elevated (III, ii) and the Comendador, eager to please, accedes saying: "Te haré caballero," thereupon Peribáñez kneels and the Comendador dubs him a knight. There is no doubt that Peribáñez accepts the ritual as a valid confirmation of his new status. He says to the Comendador:

Y pues iguales los dos con este honor me dejáis, mirado cómo le guardáis, o quejaréme de vos. 
And Casilda, when she is attempting to defend herself from the Comendador also uses her new position as protection: "Mujer soy de un capitán" (III, xvi). Both dramatically and historically (see n. 22), we have a change of social position in Peribáñez. Since Peribáñez and the Comendador are on the same social level, the ex-peasant's action cannot be seen as traitorous and therefore the integrity of his personality is kept unbroken.

This, of course, solves all ideological contradictions until one stops to consider how this transformation affects the theme of the play. According to the lines drawn by the dramatist, the reader is led to follow the development of two parallel and opposing lines: on the one hand, the Comendador with his courtly values, his social nobility and immorality; on the other, Peribáñez with his closeness to nature, his nobility of spirit and his simple state. The entire play is predicated upon this duality and the irony of the greater nobility of the lesser social being. By making Peribáñez a nobleman, Lope has perverted the entire scope of his play. We no longer have the courageous affirmation of a higher nobility which transcends the narrow scope of social position, but a simple revenge play in which one nobleman kills another. In making Peribánez leave his state, Lope has not only weakened his theme, but has indeed removed the very bases upon which the play rests.

The social and political movements, first affirmed and then subconsciously retracted, in Lope's plays deal with subjects that have become fundamental rights of Western man: personal dignity and the right of self-defense. However important they have become for us, they do not carry the emotional charge that the problem of authority and its source had for the 16th and 17th centuries. While Lope timidly advanced concepts that even then had considerable support, he never tackled a topic so fraught with danger as tyrannicide. Perhaps Lope was too much a Counter-reformation writer to attempt a full-scale treatment of such a prohibited subject. It was left to Guillén de Castro, the dramatizer of the Cid's exploits, to undertake this difficult task. It may have been his temporal proximity to the great controversy or perhaps his less than venerating attitude toward kingship that spurred him on.

In 1599, Father Juan de Mariana had published his momentous treatise on the king and the royal institution. This book had a fantastic influence on the formation of a concept then gaining ascendency in Europe, that the fundamental authority in a nation resides in the people. ${ }^{26}$ His basic argument was that when a king, because of his actions, has lost the respect and the obedience of the people he governs, he has become in fact a tyrant and as such can be removed. The doctrine of tyrannicide which was invoked by both the killers of Henry III and Henry IV of France is then given authority and an ideological underpinning. One might be surprised by the advocacy of such a concept by a Spaniard who lived under the most absolutist of the Spanish monarchs of the 16th century, but it should not be 
forgotten that this period saw a renewal of a strongly conservative ideological position vis-à-vis the problem of ultimate authority and Father Mariana is part of this current. The undermining of the absolute and divine authority of the monarch does not respond, therefore, to a modernization of this grave social problem, but an effort to reduce the power of lay authority and to restore the influence of religious force in society.

We have no way of determining whether Guillén de Castro agreed with the neo-scholastics on this point or if his perception of the question followed different lines. In any event, his El amor constante ${ }^{27}$ is the best dramatization of Mariana's view of tyrannicide that we have in the theater of the Golden Age. ${ }^{28}$ The king is a malevolent despot, given to murderous acts, violation of women, denial of his covenant with God in his renunciation of sacred matrimony. There is in the play a detailed and painstaking preparation of his unworthiness as a king. Indeed, the great bulk of the action is dedicated exactly to this purpose, as if Castro wanted to make the case against the monarch so overwhelming that no escape from the inevitable conclusion could be found. The opposition to him is equally pervasive and every social class is represented in the demonstrations against his rule. One of his courtiers remarks:

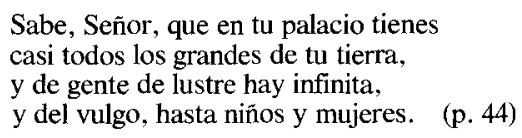

The play, as I have indicated, has the pattern of trial: presentation of evidence and final judgement. The sins of the king mount, the suffering of the people increases, the exclamations of disapproval and rebellion become more frequent. The play is built upon this ineluctible movement toward a precipitous and catastrophic ending for the evil monarch. It is not without reason that it is a grande who is made to affirm:

El rey, siendo tirano,

luego lo deja de ser. (p. 29)

But in spite of this careful preparation, in spite of the theoretical backing to be found in Mariana, in spite of the fact that the king has just been described as a monster to be exterminated, Castro, like Lope before him, does not have the courage to affirm unequivocably the right of the people to depose a tyrant. The King is deposed, to be sure, but once again in a manner which blunts the entire thrust of the preceding events. When the people, tired of his brutality, rush to the palace for the final reckoning, the king appears before them and admits the responsibility for all the evil he has done. He therefore exhorts his subjects to do away with him and exclaims: 
What, in effect, Castro has done is to bring about the removal of the king not as a result of a social action on the part of the people, which would then demonstrate their right to depose a tyrant, but as a result of the king's own realization that he has failed in his divinely appointed task. The play which at the beginning had all the ear-marks of a strong indictment against tyranny, is transformed by Castro's apparent unwillingness to challenge the concept of the divine right of kings, into a quasi-religious play in which the change occurs not through the will of the people but through the repentance of the monarch. The entire thrust of the comedia is blunted and Castro, who had built the action according to certain well-defined patterns, finds himself deviating from his purpose and doing violence to his theme.

It is quite clear that these plays present us with an opportunity to consider the Comedia differently from the way we have been thinking about it. The perception of this theater as an essentially conservative, even reactionary art has limited the scope of our criticism and has forced us to focus a bit too narrowly on certain subjects. In a fairly recent and illuminating book, José Antonio Maravall, the eminent historian, has looked at the Comedia as an arm of the propaganda machine set up by the Counter Reformation. According to this view, society sought to maintain the hierarchical social lines inherited from the Middle Ages which had been weakened by the individualism of the Renaissance. Since these values could not be accepted without question, they had to be imposed upon the people through a vast effort of persuasion. The ambiguity of the Comedia resides, then, in the realization that the division of people into estates was no longer unchallenged and in the desire of the ruling classes to see it continued. 29

While I do not wish to change this view completely, I am prepared, on the basis of the evidence adduced above, to advance a less absolutist view of this theater. It is true that the playwrights vitiated their artistic conceptions by the inability to follow through on the lines that they themselves had drawn. This incapacity can be seen variously as intellectual or physical cowardice, as lack of artistic integrity or political reaction. However, it is inescapable that the playwrights did conceive of dramatic actions whose patterns instinctively moved toward an affirmation of a social conception that was in contradiction with established values. If we grant, al least these two playwrights, a minimum of professional competence our conclusion must be that the deviation from the pattern so painstakingly prepared, cannot be due to lack of technical skill but to a conscious awareness of the ideological, if not personal, danger inherent in their themes. It is not too risky to affirm that the retraction of their convictions may be due to circumstances both psychological and historical.

This period in Europe and in Spain is not known for advancing revolutionary social ideas: it is, rather, a period of conformity and obedience to authority. Lope, in his Arte nuevo, had not been able to break away completely from the influence of literary authority although he 
suspected that his understanding of art was fully valid. In their plays, neither Lope nor Guillén de Castro was sure enough of himself to break open new grounds in social and political thinking, but both were aware that there was something of value in man that society must not eradicate. If they were not able to state it unequivocably, they were, at least, able to perceive it.

The University of Michigan

FRANK P. CASA

\section{Notes}

1. See the edition of Alfred Morel-Fatio in Bulletin Hispanique, 3 (1901), 365-405.

2. This in spite of Alonso López-Pinciano's learned commentary on Aristoteles, first published in 1596. See the edition by Alfredo Carballo Picazo of the Philosophia antigua poética (Madrid, 1953). For a discussion of Pinciano's contributions, see Sanford Shepard, El Pinciano y las teorías literarias del Siglo de Oro (Madrid, 1962).

3. The disdain for the common people is a well-documented attitude of the Renaissance, see Américo Castro, El pensamiento de Cervantes (Barcelona, 1972), pp. 213-214.

4. Some glimpses of the problem may be found in J. C. J. Metford, "The Enemies of the Theatre in the Golden Age," Bulletin of Hispanic Studies, 28 (1951), 76-92.

5. The extent of the attacks on the theater is documented in Emilio Cotarelo y Mori, Bibliografia de las controversias sobre la licitud del teatro en España (Madrid, 1904).

6. In Historia de las ideas estéticas en España (Madrid, 1942), II, 295. For an appreciation of the position of Menéndez Pelayo in Spanish literary criticism, see Bruce Wardropper, "Menéndez Pelayo on Calderón," Criticism, 7 (1965), 363-372.

7. "El Arte nuevo y la nueva biografia," in De Cervantes y Lope de Vega (Madrid, 1958), pp. 69-133.

8. A general review of the problems posed by this work is found in J. H. Parker, "Lope de Vega's Arte nuevo de hacer comedias: Post-Centenary Reflections," in Hispanic Studies in Honor of Nicholson B. Adams, ed. J. E. Keller and K-L. Selig (Chapel Hill, North Carolina, 1966), 113-130.

9. "An Introduction to the Ideology of the Baroque in Spain," Symposium, 1 (1946), $82-107$.

10. "Thus, there were two sets of artistic possibilities, possibilities for the masses who accepted in full all orthodox values and beliefs, and possibilities for the minority of cultos who did not, who proclaimed on the basis of previous argument their distinctive soledad," Gilman, p. 105.

11. On the traditional role of the writer and his subsequent awareness of social matters see, Arnold Hauser, Sozial Geschichte der Kunst und Literatur (Munich, 1953), II, 242-245.

12. These three basic studies on the play are, respectively, "A Central Theme and Its Structural Equivalent in Lope's Fuenteovejuna," Hispanic Review, 23 (1955), 274-292; " The Meaning and Structure of Lope's Fuenteovejuna; Its Platonic Vision and Execution,' Studies in Philology, 58 (1961), 179-192.

13. “Melancolía renacentista o melancolía judía?" in Estudios hispánicos: homenaje a Archer M. Huntington (Wellesley, Mass., 1952), pp. 39-50.

14. The most explicit presentation of this topic is, of course, Fray Antonio de Guevara's Menosprecio de la corte y alabanza de aldea, ed. M. Martínez de Burgos (Madrid, 1915).

15. For a study based on this assumption see, Constance Rose, Alonso Núñez de Reinoso: the Lament of a Sixteenth-Century Exile (Ruthford, N. J., 1971).

16. "Sententiousness in Fuenteovejuna," Tulane Drama Review, 7 (1962), 5-37.

17. The topos in Spanish literature has been studied by Francisco Rico in El Pequeño mundo del hombre; varia fortuna de una idea en las letras españolas (Madrid, 1970).

18. The subject is extensively treated in De la edad conflictiva (Madrid, 1961).

19. "Images et structure dans Peribáñez," Bulletin Hispanique 51 (1949), 125-159.

20. See Angel Valbuena Briones, "El simbolismo en el teatro de Calderón: la caída del caballo," Romanische Forschungen, 74 (1962), 60-76.

21. See Joseph H. Silverman, "Los 'hidalgos cansados' de Lope de Vega," in Homenaje 
a William L. Fichter: Estudios sobre el teatro antiguo hispánico y otros ensayos, ed. A. David Kossoff and José Amor y Vázquez (Madrid, 1971), 693-711.

22. Antonio Domínguez Ortiz in La sociedad española en el siglo XVII (Madrid, 1963), pp. 191-192, documents the existence of "caballeros pardos" as a means of increasing the number of soldiers who fought against the Moors. This "caballería villana" was similar to the "caballeros cuantiosos" of Andalucía.

23. The problem of obedience versus right to self-defense is discussed in Robert L. Fiore's Drama \& Ethos: Natural-Law Ethics in Spanish Golden Age Theater (Lexington, Kentucky, 1975), Chapter two. Another view can be found in Robert S. Chamberlain, "The Concept of the Señor natural as Revealed by Castilian Law and Administrative Documents," The Hispanic American Review, 19 (1939), 130-137.

24. Historically, this period sees the beginning of new theories on the relationship between governers and governed, see Herschel Baker, The Wars of Truth (Cambridge, Mass., 1952), Chapter VI; however, the Comedia still functions on the basis of a previous and idealized conception of obedience and authority.

25. "El contenido irónico-teatral en el Peribáñez de Lope de Vega," Clavileño, V, no. 29 (1954), 17-25. Sánchez' conclusion that "al matar al comendador Peribáñez no se rebela contra la nobleza, sino que castiga a un individuo noble que no supo serlo" does not consider the implication that a punishment for this type of infraction can only be meted out by someone who is socially equal or superior.

26. Del Rey y de la institución real in Obras del Padre Juan de Mariana (Madrid, 1854), $B A E$ vol. 31. A contemporary reaction to Mariana's work is seen in Michel Roussel, L'Antimariana (Paris, 1610) while a modern appreciation can be found in Guenter Lewy, Constitutionalism and Statecraft During the Golden Age of Spain: A Study of the Political Philosophy of Juan de Mariana, S. J. (Geneva, 1960).

27. See the edition of the works of Guillén de Castro by E. Juliá Martínez (Madrid, 1926).

28. The theme of tyrannicide in the comedia, found in plays such as Lope's El principe despeñado, Las almenas de Toro and Guillén de Castro's El perfecto caballero, has not yet been studied and retains therefore its ambiguity.

29. Teatro y literatura en la sociedad barroca (Madrid, 1972). 